\title{
Early neonatal mortality and risk factors: a case-control study in Paraná State
}

\author{
Mortalidade neonatal precoce e fatores de risco: estudo caso-controle no Paraná \\ Mortalidad neonatal precoz y factores de riesgo: estudio caso-control en Paraná
}

\author{
Michelle Thais Migoto', Rafael Pallisser de Oliveira", Ana Maria Rigo Silva'", Márcia Helena de Souza Freire' \\ ' Universidade Federal do Paraná. Curitiba, Paraná, Brazil. \\ "Universidade Positivo. Curitiba, Paraná, Brazil. \\ I" Universidade Estadual de Londrina. Londrina, Paraná, Brazil.
}

How to cite this article:

Migoto MT, Oliveira RP, Silva AMR, Freire MHS. Early neonatal mortality and risk factors: a case-control study in Paraná State. Rev Bras Enferm [Internet]. 2018;71(5):2527-34. DOI: http://dx.doi.org/10.1590/0034-7167-2016-0586

\section{Submission: 11-01-2016 Approval: 05-18-2018}

\section{ABSTRACT}

Objective: to analyze the Early Neonatal Mortality risk factors according to the risk stratification criteria of the Guideline of the Rede Mãe Paranaense Program. Method: a case-control epidemiological study with secondary data from the Mortality and Live Birth Information System in 2014. The crude analysis was performed by the Odds Ratio association measure, followed by the adjusted analysis, considering risk factors as independent variables, and early neonatal death as dependent variable. Results: were considered as maternal risk factors: absence of partner and miscarriages; neonatal: male, low birth weight, prematurity, Apgar less than seven in the fifth minute, presence of congenital anomaly; and care: up to six prenatal appointments. Conclusion: an innovative study of risk factors for early neonatal death from the Guideline's perspective, a technological management tool for maternal and child health, in search of its qualification and greater sensitivity.

Descriptors: Early Neonatal Mortality; Risk Factors; Public Health Nursing; Nursing; Information Systems.

\section{RESUMO}

Objetivo: analisar os fatores de risco para Mortalidade Neonatal Precoce, segundo os critérios de estratificação de risco da Linha Guia do Programa Rede Mãe Paranaense. Método: estudo epidemiológico, tipo caso-controle, com dados secundários do Sistema de Informação de Mortalidade e de Nascidos Vivos, em 2014. Foi realizada a análise bruta pela medida de associação Odds Ratio, seguida da análise ajustada, considerando as variáveis independentes os fatores de risco, e como dependente, o óbito neonatal precoce. Resultados: foram considerados como fatores de risco maternos: ausência de companheiro e perdas fetais; neonatais: sexo masculino, baixo peso ao nascer, prematuridade, Apgar menor que sete no quinto minuto, presença de anomalia congênita; e assistenciais: até seis consultas de pré-natal. Conclusão: estudo inovador de fatores de risco ao óbito neonatal precoce na perspectiva da Linha Guia, instrumento tecnológico de gestão para saúde materna e infantil, na busca de sua qualificação e maior sensibilidade. Descritores: Mortalidade Neonatal Precoce; Fatores de Risco; Enfermagem em Saúde Pública; Enfermagem; Sistemas de Informação.

\section{RESUMEN}

Objetivo: analizar los factores de riesgo para Mortalidad Neonatal Precoce, según los criterios de estratificación de riesgo de la Línea Guía del Programa Rede Mãe Paranaense (Programa Red Madre Paranaense). Método: el estudio epidemiológico, tipo caso-control, con datos secundarios del Sistema de Información de Mortalidad y de Nacidos Vivos, en 2014. Se realizó el análisis bruta por la medida de asociación Odds Ratio, seguida del análisis ajustado, considerando las variables independientes los factores de riesgo, y como dependiente, el óbito neonatal precoz. Resultados: fueron considerados como factores de riesgo materno: ausencia de compañero y pérdidas fetales; neonatales: sexo masculino, bajo peso al nacer, prematuridad, Apgar menor que siete en el quinto minuto, presencia de anomalía congénita; y asistenciales: hasta seis consultas de prenatal. Conclusión: estudio innovador de factores de riesgo al óbito neonatal precoz en la perspectiva de la Línea Guía, instrumento tecnológico de gestión para salud materna e infantil, en la búsqueda de su calificación y mayor sensibilidad. Descriptores: Mortalidad Neonatal Precoz; Factores de Riesgo; Enfermería en Salud Pública; Enfermería; Sistemas de Información. 


\section{INTRODUCTION}

In Brazil, in 2016, there were 20,176 deaths in the Early Neonatal period, constituting 53.2\% of infant deaths, with Early Neonatal Mortality Rate (ENMR) of 6.7 deaths per thousand live births $(\mathrm{LB})^{(1)}$. The first causes of these deaths were those caused by conditions originating in the perinatal period $(58.0 \%)$, followed by congenital malformations, deformities and chromosomal abnormalities $(22.0 \%)^{(2)}$. The setting of Paraná State is proportionally similar to the others in Brazil. There were 943 deaths in the first week of life, accounting for $54.1 \%$ of infant deaths, and ENMR of 5.9 deaths per thousand LB, due to the same related causes ${ }^{(1-2)}$.

In 2013, the United States ENMR was 12.9 deaths per thousand LB, as the highest component of Infant Mortality ${ }^{(3)}$. In this country, the health system is fragmented ${ }^{(4)}$ and, despite being administered by the private sector, the government spends high monetary values on health. However, the US states show high ENMR, compared to the other developed $\operatorname{countries}^{(5)}$, a fact that may reflect the difficulty of the population to access health services free of costs.

On the other hand, for the reduction of infant mortality in Portugal, access to health services was expanded, with focus on investments in public policies applied to teenagers. Policies have permeated the promotion of actions related to sex education, provision of contraceptive methods, and in addition to improving the quality of prenatal care. Thus, these Guidelines, coupled with the low birth rate setting, resulted in reduction of teenage pregnancy and a meaningful reduction of ENMR to only 1.2 deaths per thousand LB in $2013^{(6)}$.

Brazilian health system maintains some similarities with that of Portugal, considering the aspect of universal and integral access offer to the entire population, and of its expressive reduction in Infant Mortality, from 47.7 in 1990 to 14.6 deaths per thousand LB in 2012, approximately $70.0 \%$ rate decrease. However, this decline was unequal among Brazilian regions ${ }^{(7)}$, influenced by social, economic and health disparities peculiar to each one. Nevertheless, in this route there was an epidemiological signal, which constitutes a current and challenging public health problem, which is the prevalent occurrence of deaths in the early neonatal period, accounting for about $53.0 \%$ of infant deaths, especially deaths occurring in the first 24 hours of life, following a global trend that countries transit from 'developing' to 'developed'(8).

A study carried out in Paraná, from 2000 to 2006, in the Northwest Health Macro-Region have identified that $71.3 \%$ of infant deaths occurred in the neonatal period. Of these, approximately $73.0 \%$ were early neonatal deaths and due to causes related to some neonatal conditions, which are included in Chapter XVI of the $10^{\text {th }}$ Revision of the International Classification of Diseases ICD-10. Faced with the analysis of these infant deaths carried out by the Secretary's Advisory Committee on Infant Mortality (the Brazilian Comitê de Prevenção da Mortalidade Infantil), it was observed that $70.0 \%$ would have been reducible. For $53.0 \%$ of the reducible deaths of children before their seventh day of life, adequate care should have been given to gestation, labor, birth and newborn care, as this was one of the avoidability criteria ${ }^{(9)}$.

Among the reductive deaths, it was prevalent: maternal marital status without partner $(62.4 \%)$, absence of previously dead child $(84.8 \%)$, seven or more prenatal care appointments $(41.1 \%)$, gestational age of 32 weeks or more $(53.5 \%)$, normal labor (53.8\%), birth weight less than 1,499 g (46.7\%), Apgar between 8 and 10 days fifth of life, absence of congenital anomaly $(89.4 \%)$, and white race/ethnicity (almost $81.0 \%)^{(9)}$.

The Secretary's Advisory Committees on Infant and Fetal Mortality (in Brazil, there are two different Committees regarding the prevention of mortality in infants and in fetuses- Comitê de Prevenção da Mortalidade Infantil and Comitê de Prevenção da Mortalidade Fetal) have been carrying out important work in Paraná State since the 1990s in all health care spheres, such as Primary Health Care, hospitals, municipalities, health centers, and the Department of Health of Paraná State, incorporating in its composition professionals with different trainings and fronts of action in health services, education and research, with the indispensable social participation. At each sentinel event of compulsory notification, the death of less than one year of age is analyzed by the Committees members, of the respective instances, after the collection of information by the local and municipal instances of epidemiological surveillance ${ }^{(10)}$.

In 2012, yet consistent with the perspective of effective reduction of Infant Mortality, the Rede Mãe Paranaense Program (The Rede Mãe Paranaense is a Brazilian program that proposes organization of maternal and child care in prenatal care and puerperal activities and the monitoring of the growth and development of children, especially in the first year of life) was implemented, which proposed the organization of maternal and child care in Paraná, under the logic of the Health Care Network. The same has sought impact such as the qualification of prenatal care, labor, birth and newborn care, especially, from the stratification of maternal and child risk. This stratification aims at directing women's referral from the entrance to prenatal care; Primary Care services, to specialized services, according to the risk identified as an intermediate or high risk ${ }^{(11)}$.

Therefore, there is recognition that regional diversities are challenges to be overcome for the success of implementation of public health policies, as well as for research and qualification of management technologies, and maternal and child care in Paraná State. Thus, this research was developed based on the following guiding question: what risk factors for Early Neonatal Mortality could innovate in the criteria adjustments included in the Guideline of the Rede Mãe Paranaense Program, and contribute to a more sensitive stratification of the pregnant woman's and child's risk?

\section{OBJECTIVE}

To analyze the risk factors for Early Neonatal Mortality, according to the risk stratification criteria of the Guideline of the Rede Mãe Paranaense Program.

\section{METHOD}

\section{Ethical aspects}

This article respecting the ethical precepts in research with human beings, according to Resolution 466 of $2012^{(12)}$, was approved by the Research Ethics Committee of the Universidade Federal do Paraná. It was elaborated according to the criteria of the STROBE Initiative ${ }^{(13)}$. 


\section{Study design, place and period}

This is a quantitative, epidemiological, casecontrol approach that analyzed all secondary records of live births of mothers living in Paraná. This State has 399 municipalities, and the Health services are organized into 22 Regional Health Units, which comprise four Macro-region Health Units, which mobilize logic, spatial and structural, for the organization of care in the Rede de Atenção à Saúde Materna e Infantil (Maternal and Child Health Care Network).

Population and inclusion and exclusion criteria

All the records of live births of mothers residing in the state of Paraná were analyzed. The "control" group consisted of all live births between 01/01/2014 and $12 / 25 / 2014$, totaling 157,629 children. The "case" group was composed of deaths occurred in the Early Neonatal period, between 01/01/2014 and 12/31/2014, with 903 children. Early neonatal death is the death that occurs after birth until the child's sixth full day of life, and they are part of the ENMR, this rate is an indicator that reflects regional social and economic conditions, as well as the quality of care provided in prenatal care, labor, birth and to the newborn ${ }^{(14)}$.

\section{Study Protocol}

Data from the Live Birth Information System (SINASC) and the Brazil Mortality Information System (SIM) were used and were supplied by data from the Certificate of Live Birth and the Death Certificate, respectively. These were made available by the Secretary of Health of Paraná State, in a Tabwin database, which were imported into the Microsoft Office Excel 2016 Program.

The linkage technique was used for the union of the databases, using the number of the Certificate of Live Birth as a univocal term. Of the 983 early deaths identified on the basis of SIM, only 903 $(91.9 \%)$ were found in the SINASC database, and thus, 80 (8.1\%) resulted in loss (Figure 1). According to Romero and Cunha ${ }^{(15)}$ the data worked in this research are considered of good quality.

The dependent variable was early neonatal death, and the independent variables were organized into four groups: 1 . Maternal socioeconomic conditions (age, schooling, marital status and race); 2. Maternal obstetric (live children, miscarriages and type of pregnancy); 3 . Regarding the newborn (gender, weight, gestational age, Apgar at the fifth minute and congenital anomaly); 4. Assistance (prenatal care onset, number of appointments and type of labor).

It is important to point out that, regarding the criteria currently pointed out in the Guidelines for the stratification of maternal intermediate risk, the characteristics of pregnant women (race, ethnicity and age), socioeconomic status (schooling) and obstetrics (previous story of a dead child and multiparity). For stratification as high risk, pre-existing clinical conditions (chronic or mental diseases, dependence on illegal drugs, and bariatric surgery) are considered, as well as all the clinical diseases and intercurrences presented after gestation onset ${ }^{(11)}$.
And for the child to be stratified as intermediate risk, she must meet one of the following criteria: be the daughter of a black or indigenous, under 15 years old or over 40 years old, illiterate or with less than three years of study, who had miscarriage, stillborn or infant death, or had maternal death mothers. And to be classified as high risk, you must have suffered one of the following events: severe asphyxia at birth (Apgar less than seven in the fifth minute of life), low birth weight, developing severe malnutrition, poor growth and development, presenting infectious diseases by vertical transmission (toxoplasmosis, syphilis and HIV), or Neonatal Screening Test with positive result ${ }^{(11)}$.

The "not informed" category consisted of situations of lack of information in the secondary databases' fields, added to the fields with codes that did not agree with the bank's data dictionary, because its interpretation would be impeded.

\section{Analysis of results and statistic}

Initially, the data was imported from Tabwin and organized with the support of the Microsoft Office Excel 2016 program, for grouping into categories relative to each variable. Then, a crude analysis was performed by the crude Odds Ratio (OR) measure to verify the relationship between risk factors with early neonatal death, with a $95.0 \%$ confidence interval, and a $5.0 \%$ significance level, and the support of SPSS 22.0.0.0 Program. Afterwards, the logistic regression was used to evaluate the possible confounding variables. Only those variables that presented a significance value lower than $0.20(p<0.20)$ were used, using SPSS 22.0.0.0, with the same confidence intervals and significance levels for the adjusted OR results. 


\section{RESULTS}

With the analysis of the association of socioeconomic variables, maternal age points to a greater chance of early neonatal death among teenage mothers and those who were 35 and over when compared to mothers aged 20 to 34 years. As for schooling, mothers of children who died before completing one week of life studied until the age of seven. Also, children of women who had no partner were more likely to die when compared to women who were married or in the secondary records. Regarding the categorized maternal race/ color, there was no significant difference for early neonatal death (Table 1).

Among the obstetric variables, it was highlighted: a greater chance for the occurrence of early neonatal death for multiparous women with three or more children and who presented previous miscarriage. In relation to the current pregnancy variable, there was a greater chance of death for multiple pregnancies when compared to single pregnancies (Table 1).

In the approach to the variables of the newborn, there was a greater chance of early neonatal death for: male, low birth weight, preterm infants, with Apgar asphyxia in the fifth minute of life, and those with congenital anomaly visible to the birth; with higher risk for those with extremely low birth weight $(<1,000 \mathrm{~g})$ and extreme preterm infants ( $<32$ weeks) (Table 1$)$.
According to the assistance variables, a higher probability of early neonatal death was observed in the children of women who performed up to six visits, when compared to those who performed seven or more. There was no significant statistical analysis for women who started prenatal care in the second or third quarter when compared to those who started the first one. It was observed that the c-section labor was a protective factor at death, with a $38.0 \%$ greater chance of newborn survival in the crude analysis, however, it was not significant in the adjusted analysis (Table 1).

After the application of the crude OR association test, the adjusted analysis was performed, as shown in Table 1, emphasizing that many of the significant variables in the crude analysis were no longer adjusted as: maternal age, maternal schooling, alive children, type of gestation, prenatal onset and type of labor.

Table 2 synthetizes the risk factors for early neonatal death in Paraná State and its presence or absence in the list of criteria for risk stratification of pregnant women and children. Five of the variables, defined as risk factors by means of an adjusted analysis are indicated that are not included in the Guideline as the guiding criterion for the classification of the risk by the health professional, those related to the pregnant woman: without partner and who performed up to six prenatal appointments; and for the child: male, extreme premature and congenital anomaly.

Table 1 - Proportional distribution, bivariate analysis between Crude Odds Ratio and multiple analysis Adjusted Odds Ratio risk factors for Early Neonatal Mortality categorized into maternal socioeconomic conditions, obstetric, newborn, and assistance variables according to the case group (deaths) and control groups (survivors), Paraná State, Brazil, 2014

\begin{tabular}{|c|c|c|c|c|c|c|c|c|c|c|}
\hline \multirow{2}{*}{ Variables } & \multicolumn{2}{|c|}{ Control Groups } & \multicolumn{2}{|c|}{ Case Groups } & \multicolumn{3}{|c|}{ Crude OR* } & \multicolumn{3}{|c|}{ Adjusted OR* } \\
\hline & $\mathbf{n}$ & $\%$ & $\mathbf{n}$ & $\%$ & OR* & $\mathrm{Cl} 95 \% * *$ & $p^{* * *}$ & OR* & $\mathrm{Cl} 95 \% * *$ & $p^{* * *}$ \\
\hline \multicolumn{11}{|c|}{ Group 1: Socioeconomic Maternal Conditions Variables } \\
\hline \multicolumn{11}{|l|}{ Mother's Age (years) } \\
\hline Up tp 19 & 28056 & 17.8 & 204 & 22.6 & 1.40 & $1.20-1.65$ & $<0.0001$ & 1.03 & $0.82-1.28$ & 0.803 \\
\hline From 20 to 34 & 114280 & 72.5 & 592 & 65.6 & 1.00 & - & - & 1.00 & - & - \\
\hline Over 35 & 15292 & 9.7 & 107 & 11.8 & 1.35 & $1.10-1.66$ & 0.005 & 1.11 & $0.85-1.45$ & 0.451 \\
\hline Not informed & 1 & 0.0 & 0 & 0.0 & & & & & & \\
\hline \multicolumn{11}{|l|}{ Schooling (years) } \\
\hline$<8$ & 62023 & 39.3 & 574 & 39.3 & 11.46 & $10.00-13.13$ & $<0.0001$ & 1.27 & $0.94-1.34$ & 0.187 \\
\hline$\geq 8$ & 94994 & 60.3 & 327 & 60.3 & 1.00 & - & & 1.00 & - & - \\
\hline Not informed & 612 & 0.4 & 2 & 0.4 & & & & & & \\
\hline \multicolumn{11}{|l|}{ Marital Status } \\
\hline With a partner & 60498 & 38.4 & 272 & 30.1 & 1.00 & - & - & - & - & - \\
\hline Without a partner & 96433 & 61.2 & 624 & 69.1 & 1.44 & $1.25-1.66$ & $<0.0001$ & 1.22 & $1.00-1.49$ & 0.043 \\
\hline Not informed & 698 & 0.4 & 7 & 0.8 & & & & & & \\
\hline \multicolumn{11}{|l|}{ Race } \\
\hline White and yellow & 120061 & 76.2 & 686 & 76.0 & 1.00 & - & - & & & \\
\hline Brown & 31659 & 20.1 & 181 & 20.0 & 1.00 & $0.85-1.18$ & 0.9723 & & & \\
\hline Black & 3760 & 2.4 & 22 & 2.4 & 1.02 & $0.67-1.57$ & 0.9996 & - & - & - \\
\hline Indigenous & 471 & 0.3 & 3 & 0.3 & 1.11 & $0.36-3.48$ & 0.9054 & & & \\
\hline Not informed & 1678 & 1.1 & 11 & 1.2 & & & & & & \\
\hline
\end{tabular}




\begin{tabular}{|c|c|c|c|c|c|c|c|c|c|c|}
\hline \multirow{2}{*}{ Variables } & \multicolumn{2}{|c|}{ Control Groups } & \multicolumn{2}{|c|}{ Case Groups } & \multicolumn{3}{|c|}{ Crude OR* } & \multicolumn{3}{|c|}{ Adjusted OR* } \\
\hline & $\mathbf{n}$ & $\%$ & $\mathbf{n}$ & $\%$ & $\mathrm{OR}^{*}$ & $\mathrm{Cl} 95 \% * *$ & $\boldsymbol{p}^{* * *}$ & $\mathrm{OR}^{*}$ & $\mathrm{Cl} 95 \% * *$ & $\boldsymbol{p}^{* * *}$ \\
\hline \multicolumn{11}{|c|}{ Group 2: Obstetric Variables } \\
\hline \multicolumn{11}{|l|}{ Alive Children } \\
\hline$\leq 2$ & 144702 & 91.8 & 818 & 91.8 & 1.00 & - & - & - & - & - \\
\hline$\geq 3$ & 11791 & 7.5 & 85 & 7.5 & 1.27 & $1.02-1.59$ & 0.0386 & 1.02 & $0.753-1.39$ & 0.880 \\
\hline Not informed & 1136 & 0.7 & 0 & 0.7 & & & & & & \\
\hline \multicolumn{11}{|l|}{ Miscarriages } \\
\hline No & 132839 & 84.3 & 714 & 79.1 & 1.00 & - & - & 1.00 & - & - \\
\hline Yes & 23390 & 14.8 & 188 & 20.8 & 1.49 & $1.27-1.76$ & $<0.0001$ & 1.25 & $1.00-1.55$ & 0.041 \\
\hline Not informed & 1400 & 0.9 & 1 & 0.1 & & & & & & \\
\hline \multicolumn{11}{|l|}{ Type of Pregnancy } \\
\hline Single & 154261 & 97.8 & 790 & 97.8 & 1.00 & - & - & 1.00 & - & - \\
\hline Multiple & 3263 & 2.1 & 113 & 2.1 & 6.76 & $5.53-8.26$ & $<0.0001$ & 0.96 & $0.72-1.29$ & 0.810 \\
\hline Not informed & 105 & 0.1 & 0 & 0.0 & & & & & & \\
\hline \multicolumn{11}{|c|}{ Group 3: Newborn Variables } \\
\hline \multicolumn{11}{|l|}{ Gender } \\
\hline Female & 76774 & 48.7 & 399 & 44.2 & 1.00 & - & - & 1.00 & - & - \\
\hline Male & 80847 & 51.3 & 496 & 54.9 & 1.18 & $1.03-1.35$ & 0.0151 & 1.35 & $1.14-1.60$ & 0.001 \\
\hline Not informed & 8 & 0.0 & 8 & 0.9 & & & & & & \\
\hline \multicolumn{11}{|l|}{ Weight (g) } \\
\hline$<1.000$ & 503 & 0.3 & 385 & 42.6 & 577.16 & $475.36-700.75$ & $<0.0001$ & 36.60 & $25.83-51.84$ & 0.000 \\
\hline From 1.000 to 2.499 & 12337 & 7.8 & 326 & 36.1 & 19.92 & $16.65-23.84$ & $<0.0001$ & 4.43 & $3.42-5.73$ & 0.000 \\
\hline$\geq 2.500$ & 144779 & 91.8 & 192 & 21.3 & 1.00 & - & - & 1.00 & & - \\
\hline Not informed & 10 & 0.0 & 0 & 0.0 & & & & & & \\
\hline \multicolumn{11}{|l|}{ Gestational Age (week) } \\
\hline$>37$ & 140477 & 89.1 & 212 & 23.5 & 1.00 & - & - & 1.00 & - & - \\
\hline From 32 to 37 & 13893 & 8.8 & 170 & 18.8 & 8.11 & $6.62-9.93$ & $<0.001$ & 2.33 & $1.78-3.03$ & 0.000 \\
\hline$<32$ & 1791 & 1.1 & 516 & 57.1 & 190.90 & $161.62-225.50$ & $<0.001$ & 6.98 & $5.10-9.54$ & 0.000 \\
\hline Not informed & 1468 & 0.9 & 5 & 0.6 & & & & & & \\
\hline \multicolumn{11}{|l|}{ Ápgar $5^{\text {th }} \min$ (scores) } \\
\hline$<7$ & 1607 & 1.0 & 480 & 53.2 & 110.93 & $96.45-127.58$ & $<0.0001$ & 13.93 & $11.43-16.97$ & 0.000 \\
\hline$\geq 7$ & 155982 & 98.9 & 420 & 46.5 & 1.00 & - & - & 1.00 & - & - \\
\hline Not informed & 40 & 0.0 & 3 & 0.3 & & & & & & \\
\hline \multicolumn{11}{|l|}{ Congenital Anomaly } \\
\hline No & 156333 & 99.2 & 742 & 82.2 & 1.00 & - & - & 1.00 & - & - \\
\hline Yes & 954 & 0.6 & 159 & 17.6 & 35.11 & $29.25-42.15$ & $<0.0001$ & 21.82 & $16.74-28.44$ & 0.000 \\
\hline Not informed & 342 & 0.2 & 2 & 0.2 & & & & & & \\
\hline
\end{tabular}

\section{Group 4: Assistance Variables}

\begin{tabular}{|c|c|c|c|c|c|c|c|c|c|c|}
\hline \multicolumn{11}{|l|}{ Prenatal Onset } \\
\hline $1^{\text {st }}$ Quarter & 129524 & 82.2 & 666 & 73.8 & 1.00 & - & - & 1.00 & - & - \\
\hline $2^{\text {nd }}$ or $3^{\text {rd }}$ Quarter & 22838 & 14.5 & 149 & 16.5 & 1.27 & $1.06-1.52$ & 0.0100 & 1.10 & $0.87-1.41$ & 0.399 \\
\hline Not informed & 5267 & 3.3 & 88 & 9.7 & & & & & & \\
\hline \multicolumn{11}{|c|}{ Number of Appointments } \\
\hline From 0 to 6 & 29488 & 18.7 & 539 & 59.7 & 6.82 & $5.95-7.82$ & 0.0001 & 1.53 & $1.25-1.87$ & 0.000 \\
\hline $\begin{array}{l}\geq 7 \\
\text { Not informed }\end{array}$ & $\begin{array}{c}127643 \\
498\end{array}$ & $\begin{array}{l}81.0 \\
0.3\end{array}$ & $\begin{array}{c}342 \\
22\end{array}$ & $\begin{array}{l}37.9 \\
2.4\end{array}$ & 1.00 & - & - & 1.00 & - & - \\
\hline \multicolumn{11}{|l|}{ Type of Labor } \\
\hline Normal & 57714 & 36.6 & 435 & 48.2 & 1.00 & - & - & 1.00 & - & - \\
\hline C-section & 99847 & 63.3 & 468 & 51.8 & 0.62 & $0.54-0.70$ & $<0.0001$ & 1.01 & $0.85-1.22$ & 0.865 \\
\hline Not informed & 68 & 0.0 & 0 & 0.0 & & & & & & \\
\hline
\end{tabular}

Note: *Odds Ratio, $* *$ Confidence Level of $95 \%, * * * P$ value. 
Table 2 - Synthesis of risk factors for early neonatal death in the state of Paraná according to groups of variables and multiple analysis adjusted Odds Ratio, Paraná State, Brazil, 2014

\begin{tabular}{|c|c|c|c|c|}
\hline Adjusted Variable & OR adj* & $\mathrm{Cl} 95 \% * *$ & $\boldsymbol{p}^{* * *}$ & Guideline Classification \\
\hline \multicolumn{5}{|l|}{ Maternal socioeconomic conditions } \\
\hline Without partner & 1.22 & $1.00-1.49$ & 0.043 & Not included \\
\hline \multicolumn{5}{|l|}{ Obstetric } \\
\hline Miscarriages & 1.25 & $1.00-1.55$ & 0.041 & Intermediate risk of the pregnant woman \\
\hline \multicolumn{5}{|l|}{ Of the Newborn } \\
\hline Male & 1.35 & $1.14-1.60$ & 0.001 & Not included \\
\hline Extreme premature (<32 week) & 6.98 & $5.10-9.54$ & 0.000 & Not included \\
\hline Apgar $<7$ in the fifth minute & 13.93 & $11.43-16.97$ & 0.000 & High risk of the child \\
\hline Presence of congenital anomaly & 21.82 & $16.74-28.44$ & 0.000 & Not included \\
\hline Low birth weight $(<1.000 \mathrm{~g})$ & 36.60 & $25.83-51.84$ & 0.000 & High risk of the child \\
\hline \multicolumn{5}{|l|}{ Assistance } \\
\hline Up to six prenatal appointments & 1.53 & $1.25-1.87$ & 0.000 & Not included \\
\hline
\end{tabular}

Note: *Adjusted Odds Ratio;**Confidence Interval of $95 \% ; * * * P$ value.

\section{DISCUSSION}

The main determining factors were identified with an adjusted analysis of the risk factors and were related, especially to the characteristics of the newborn, such as: male, low birth weight, prematurity, Apgar less than seven in the fifth minute of life and, presence of congenital anomaly; maternal socioeconomic conditions, influenced by the marital situation; and obstetric history with history of previous miscarriage; as well as related to the conditions of care, such as less than seven visits.

However, the chance of early neonatal death related to low birth weight, the presence of congenital anomaly and Apgar is, respectively, almost 35, around 20 and 13 times higher than in children who do not present these factors. Extreme preterm infants (gestational age $<32$ weeks) are almost six times more likely to die than non-premature infants. While the pregnant woman who does not have a partner, who has presented miscarriage in a previous gestation and who has performed up to six prenatal visits, have a $50.0 \%$ chance of having early neonatal death, when compared to those who have a partner, who never had miscarriages and who performed more than six prenatal appointments.

A case-control study, carried out in Fortaleza city, corroborates the present study when analyzing the neonatal deaths, since it identified a greater chance of neonatal mortality, among deaths in the first week of life, especially on the first day, where there was about a third of deaths. The study points to prematurity $(<37$ weeks), low birth weight $(<2,500 \mathrm{~g})$ and Apgar in the fifth minute lower than seven ${ }^{(16)}$ as predictors of neonatal death.

Another study states the need for tracheal intubation to increase the chance of death by $95.0 \%$ and recommends the use of surfactant as a protector, increasing survival by $46.0 \%{ }^{(17)}$. Interventions such as these are applied to extreme premature infants, who are underweight, or who present respiratory insufficiency due to poor birth conditions, related to Apgar values in the fifth minute below seven. Also, a national study points to a 15-fold higher chance of death for newborns with Apgar less than seven, and 32 times more chance for those under $1,500 \mathrm{~g}^{(18)}$.
It is observed that the incidence of preterm birth is increasing and may be related to the difficulty of access to health services, in addition to the low quality of care offered in prenatal care, labor, birth and newborn care. It is estimated that investments in maternal and child care may impact on a reduction of approximately $70.0 \%$ of early neonatal deaths, as well as stillbirths ${ }^{(7)}$.

There was a higher probability of early neonatal death for male children $(35.0 \%)$, when compared to the female gender. This association was also identified by another study ${ }^{(16)}$, through the Nascer no Brasil survey (Brazilian survey on childbirth and birth), which identified a higher proportion of female birth, diverging from this study. However, it also showed higher mortality for males with statistical significance for all Brazilian regions ${ }^{(18)}$.

The presence of a congenital anomaly visible at birth increased the chance of early neonatal death in a little more than 21-fold (OR: 21.82), when compared to infants who did not present them. In Brazil, this risk was lower (OR: 16.55), presenting as the second cause of death, overcome only by prematurity ${ }^{(18)}$. Due to its magnitude, the early diagnosis of congenital anomalies is a quality standard in prenatal care, since it allows the planning of labor in services that provides the necessary support to assure the survival of newborns with congenital anomaly. And, there is a need for greater technological and technical investments in reproductive planning, in order to provide strategies for the diagnosis and reduction of congenital anomalies, especially in situations of unplanned pregnancy that impact the late onset of prenatal care and/or noncompliance with this monitoring.

The children of unmarried women, according to secondary registries, presented a $22.0 \%$ greater chance of early neonatal death when compared to those who declared themselves to be married or amassed. In the Brazilian scenario, it was found that women with no partner at the time of labor had a $55.0 \%$ chance of having their child dead until the day of life ${ }^{(18)}$, well above what was identified in the present study. A study carried out in Fortaleza city did not find statistical significance in the analysis of the pregnant woman's marital status related to neonatal death ${ }^{(16)}$.

However, a study conducted in Rio de Janeiro city, which analyzed the vertical transmission of congenital syphilis, pointed 
to the presence of a partner as a protective factor for this infection $^{(19)}$. It is observed that there are several scientific evidences that the marital status is related to the early neonatal survival. However, this relationship is not exclusive because it suffers the influence of the socioeconomic conditions of the region, which impact on the peculiarities of care and morbidity and mortality, to be considered by public health policies.

Previous history of miscarriage presented a greater chance of death (OR: 1.25) in the early neonatal period, that is, $25.0 \%$ more when compared to women who did not report this event in previous pregnancies. This association was identified in a Brazilian national survey, however, with a risk almost three times higher (OR: 3.62) than in Paraná State ${ }^{(18)}$. In Fortaleza, the chance of death was greater than twice (OR: 2.69), when compared to women who did not present any previous miscarriage ${ }^{(16)}$. It is necessary to include clinical investigation for possible causes of intrauterine deaths before the new pregnancy, to establish the planning of preventive actions and avoid reoccurrence.

Women who performed up to six prenatal care appointments showed a greater chance for the occurrence of early neonatal death $(50.0 \%)$, when compared to those who performed seven or more. According to the World Health Organization recommendation, each pregnant woman should perform at least one monthly appointment until the twenty-eighth week $^{(20)}$.

Differences were also identified in the monitoring of six or more appointments, in the Nascer no Brasil survey, highlighting the Southeast region with greater coverage $(79.7 \%)$, followed by the South region $(77.8 \%)$, however the North region with lower coverage $(57.3 \%)^{(21)}$. These percentages are still deficient even with the implementation and implementation of the public health policy focused on maternal and child care throughout Brazil. This fact justifies the need for investments in reproductive planning, in order to guarantee contraceptive methods as well as health education, bonding between women and the Primary Care service, which, consequently, are expected to reflect in adherence to follow-up prenatal care.

It is understood that the timely prevention of injuries during the gestational process is possible by the monitoring and follow-up of the woman from the suspicion or confirmation of the gestational process ${ }^{(11)}$, which can be favored by the planning of the pregnancy and the active search in Primary Care. However, the number of appointments greater than seven to be considered a quality indicator still requires a more detailed analysis. For seven or more appointments may be related to the fact that they are high-risk pregnant women, with a greater need for the service. A good information system is essential for the management of pregnant women and high-risk children, in order to facilitate the evaluation through prenatal care monitoring data.

\section{Study limitation}

Although SINASC in Paraná State can be considered of excellent quality, it was identified the absence of information on the number of the Declaration of Live Births in the records of the SIM database, as the main limitation of this study, as well as the lack of information in databases or codes not understandable by the data dictionary, and the questioning about the reliability of the secondary data worked here. Therefore, it is stated that for the maintenance of a quality standard, periodic supervision is necessary for the identification of regular quality records, and the establishment of training strategies for the professionals who fill these documents ${ }^{(22-23)}$.

Contributions to the sectors of Nursing, Health, or Public Policy This research contributes to the public policy of maternal and child health care in the State of Paraná, with new information that may provide decision making by local managers, with more sensitive indicators for the epidemiological surveillance by the CPMIF. Thus, the implementation of the Guideline as an audited tool seeks to provide and guarantee the quality of prenatal care, labor, birth and care to the newborn, implementing the assistance of the entire multiprofessional team, especially the Nursing team.

\section{CONCLUSION}

The innovative nature of this research is due to the fact that this is an unheard study on risk factors for early neonatal deaths from the Guideline's perspective, considering it as a maternal and child care management technology in Paraná. Thus, the pregnant woman's intermediate risk criterion confirms the previous history of miscarriage or stillbirth, with the suggestion of inclusion of the marital status, and absence of partner. As for the child, new criteria are proposed to be added to intermediate risk stratification, such as: being a product of gestation with a number of appointments less than seven, being male, being the mother of a previous history of stillbirth regardless of maternal age, and having congenital anomaly. Even for the child, besides confirming as a high-risk criterion low birth weight, Apgar less than seven in the fifth minute of life. It is suggested the inclusion of prematurity, with gestational age less than 37 weeks at birth.

It emphasizes the need for investments in the investigation of miscarriage, in reproductive planning, and in the knowledge of the magnitude of deaths due to congenital anomalies. It is also considered the need for the development of new state surveys that favor the evaluation of the Rede de Atenção à Saúde Mãe Paranaense's impact, so that efforts are more strongly undertaken to reduce early neonatal mortality.

\section{REFERENCES}

1. Brasil. Ministério da Saúde. Departamento de Informática do Sistema Único de Saúde (DATASUS). Estatísticas Vitais[Internet]. 2016[cited 2017 Aug 02]. Available from: http://www2.datasus.gov.br/DATASUS/index.php?area $=0205 \& i d=6938 \& V O b j=h t t p: / /$ tabnet.datasus.gov.br/cgi/deftohtm.exe?sim/cnv/inf10

2. Brasil. Ministério da Saúde. Coordenação Geral de Informação e Análise Epidemiológica. Painel de Monitoramento da Mortalidade Infantil e Fetal. 2016[cited 2017 Aug 02]. Available from: http://www2.datasus.gov.br/DATASUS/index.php?area =0205\&id=693 
$8 \& \mathrm{VObj}=\mathrm{http}: / /$ tabnet.datasus.gov.br/cgi/deftohtm.exe?sim/cnv/inf10

3. Macdorman MF, Gregory ECW. Fetal and Perinatal Mortality: United States, 2013. National Vital Statistics Reports[Internet]. 2015[cited 2016 Sep 26];64(8):1-24. Available from: http://europepmc.org/abstract/med/26222771

4. Iriart C. El sistema de salud de los Estados Unidos: mitos y realidades (Parte I). Saúde em Redes[Internet]. 2016 [cited 2016 Sep 26];2(1):07-21. Available from: http://dx.doi.org/10.18310/2446-4813.2016v2n1p07-21

5. Iriart C. El sistema de salud de los Estados Unidos: mítos y realidades (Parte II). Saúde em Redes[Internet]. 2016 [cited 2016 Sep 26];2(2):125-139. Available from: http://dx.doi.org/10.18310/2446-4813.2016v2n2p125-139

6. Portugal. Governo de Portugal. Direção Geral da Saúde. A Saúde dos Portugueses: perspectiva 2015[Internet]. 2015[cited 2016 Sep 26]. Available from: http://www.dgs.pt/estatisticas-de-saude/estatisticas-de-saude/publicacoes/a-saude-dos-portuguesesperspetiva-2015.aspx

7. Brasil. Ministério da Saúde. Secretaria de Ciência, Tecnologia e Insumos Estratégicos. Departamento de Ciência e Tecnologia. Síntese de Evidências para Política de Saúde: reduzindo a mortalidade perinatal. Brasília: Ministério da Saúde, 2013.

8. Brasil. Ministério da Saúde. Secretaria de Vigilância em Saúde. Departamento de Análise de Situação em Saúde. Saúde Brasil 2013: uma análise da situação de saúde e das doenças transmissíveis relacionadas à pobreza. Brasília: Ministério da Saúde, 2014.

9. Vianna RCXF, Freire MHS, Carvalho D, Migoto MT. Perfil da Mortalidade Infantil nas Macrorregionais de Saúde de um estado do sul do Brasil, no triênio de 2012-2014. Esp Saúde: Rev Saúde Pública[Internet]. 2016[cited 2017 Aug 06];17(2). Available from: http://www.uel.br/revistas/uel/index.php/espacoparasaude/article/viewFile/26819/1

10. Vianna RCXF, Trindade C, Freire MHS, Mansano N. Sistema de informação para a investigação da Mortalidade Infantil no Estado do Paraná. Rev ISLA. 2015;2:96-110.

11. Paraná. Secretaria do Estado de Saúde do Paraná. Superintendência da Atenção à Saúde. Linha Guia: Rede Mãe Paranaense[Internet]. 2013[cited 2016 Sep 26]. Available from: http://www.saude.pr.gov.br/arquivos/File/LinhaGuiaMaeParanaense final 2017.pdf

12. Brasil. Resolução 466[Internet]. 2012[cited 2016 Sep 26]. Available from: http://bvsms.saude.gov.br/bvs/saudelegis/cns/2013/ res0466 1212 2012.html.

13. Malta M, Cardoso LO, Bastos FI, Magnanini MMF, Silva CMFP. STROBE initiative: guidelines on reporting observational studies. Rev Saúde Pública[Internet]. 2010[cited 2016 Sep 26];44(3):559-65. Available from: http://dx.doi.org/10.1590/S0034-89102010000300021

14. Brasil. Ministério da Saúde. Secretaria de Vigilância em Saúde. Manual de vigilância do óbito infantil e fetal e do Comitê de Prevenção do Óbito Infantil e Fetal. 2. Ed. Brasília: Ministério da Saúde; 2009.

15. Romero DE, Cunha CB. Avaliação da qualidade das variáveis epidemiológicas e demográficas do Sistema de Informação sobre Nascidos Vivos, 2002. Cad Saúde Pública[Internet]. 2007[cited 2016 Sep 26];23(3):701-14. Available from: http://dx.doi.org/10.1590/ S0102311X2007000300028

16. Nascimento RM, Leite AJM, Almeida MNGS, Almeida PC, Silva CF. Determinantes da mortalidade neonatal: estudo caso-controle em Fortaleza, Ceará, Brasil. Cad Saúde Pública[Internet]. 2012[cited 2016 Sep 27];28(3):559-72. Available from: http://www.scielo. $\mathrm{br} / \mathrm{pdf} / \mathrm{csp} / \mathrm{v} 28 \mathrm{n} 3 / 16 . \mathrm{pdf}$

17. Silva CF, Leite AJM, Almeida NMGS, Leon ACMP, Olofin I. Fatores associados ao óbito neonatal de recém-nascidos de alto risco: estudo multicêntrico em Unidades Neonatais de Alto Risco no Nordeste brasileiro. Cad Saúde Pública[Internet]. 2014 [cited 2016 Sep 27];30(2):355-68. Available from: http://dx.doi.org/10.1590/0102311-X00050013

18. Lansky S, Friche AAL, Silva AAM, Campos D, Bittencourt SDA, Carvalho ML, et al. Pesquisa Nascer no Brasil: perfil da mortalidade neonatal e avaliação da assistência à gestante e ao recém-nascido. Cad Saúde Pública[Internet]. 2014[cited 2016 Sep 27];30:S192-S207. Available from: http://dx.doi.org/10.1590/0102-311X00133213

19. Domingues RMSM, Saraceni V, Hartz ZMA, Leal MC. Congenital syphilis: a sentinel event in antenatal care quality. Rev Saúde Pública[Internet]. 2013[cited 2016 Sep 26];47(1). Available from: http://dx.doi.org/10.1590/S0034-89102013000100019

20. Brasil. Ministério da Saúde. Secretaria de Atenção à Saúde. Departamento de Atenção Básica. Atenção ao pré-natal de baixo risco. Brasília: Ministério da Saúde, 2012.

21. Viellas EF, Domingues RMSM, Dias MAB, Gama SGN, Theme-Filha MM, Costa JV, et al. Prenatal care in Brazil. Cad Saúde Pública[Internet]. 2014[cited 2016 Sep 27];30:S85-S100. Available from: http://dx.doi.org/10.1590/0102-311X00126013

22. Oliveira MM, Andrade SSCA, Dimech GS, Oliveira JCG, Malta DC, Rabello-Neto DL, et al. Evaluation of the National Information System on Live Births in Brazil, 2006-2010. Epidemiol Serv Saúde[Internet]. 2015[cited 2016 Sep 26];24(4):629-40. Available from: https://dx.doi.org/10.5123/S1679-49742015000400005

23. Silva RS, Oliveira CM, Ferreira DKS, Bonfim CV. Avaliação da completitude das variáveis do Sistema de Informações sobre Nascidos Vivos-SINASC nos Estados da região Nordeste do Brasil, 2000 e 2009. Epidemiol Serv Saúde[Internet]. 2013 [cited 2016 Set 26];22(2):347-52. Available from: http://dx.doi.org/10.5123/S1679-49742013000200016 